\title{
Biochemical and hematological analysis in acute intermittent porphyria (AIP): a case report
}

\author{
ANNA R.R. DOS SANTOS ${ }^{1}$, RAFAELA R. DE ALBUQUERQUE ${ }^{1}$, \\ MARIA J.R. DORIQUI ${ }^{2}$, GRACIOMAR C. $\operatorname{COSTA}^{1}$ and ANA PAULA S.A. DOS SANTOS ${ }^{1}$ \\ ${ }^{1}$ Departamento de Ciências Fisiológicas, Universidade Federal do Maranhão, \\ Avenida dos Portugueses, 1966, Bacanga, 65085-580 São Luís, MA, Brasil \\ ${ }^{2}$ Medical Center Renascença, Av. Cel. Colares Moreira, 555, Renascença II, 65075-441 São Luís, MA, Brasil \\ Manuscript received on December 20, 2011; accepted for publication on January 10, 2013
}

\begin{abstract}
Acute intermittent porphyria is the most common acute porphyria caused by a decrease in hepatic porphobilinogen deaminase activity, resulting in an accumulation of delta-aminolevulinic acid and porphobilinogen. This disease shows nonspecific signs and symptoms that can be confused with other diseases, thereby making the diagnosis difficult. We report a case of acute intermittent porphyria, reviewing clinical and laboratory aspects, highlighting the hematological and biochemical parameters during and after the crisis. A female patient, aged 28 years, suffered two crises, both presenting gastrointestinal disorders. The second presented neuropsychiatric symptoms. The analysis of hematological and biochemical parameters during the second crisis showed anemia, leukocytosis, hyponatremia, mild hypokalemia, uremia and elevated C-reactive protein. The initial treatment included glucose infusion, a diet rich in carbohydrates and interruption of porphyrinogenic drugs. Subsequently, treatment was maintained with oral contraceptive use. According to the observed data, signs and symptoms of gastrointestinal, neurological and psychiatric disorders, associated with laboratory results presented in this paper can be applied to screen acute porphyria, contributing to early diagnosis.
\end{abstract}

Key words: acute intermittent porphyria, anemia, C-reactive protein, hyponatremia.

\section{INTRODUCTION}

Porphyrias are a group of genetic or acquired diseases, caused by abnormalities of heme biosynthesis due to enzyme defects in this pathway, resulting in excessive production and excretion of porphyrins (Murray et al. 2007). Acute intermittent porphyria (AIP) is an autosomal dominant porphyria, resulting from a disturbance of heme biosynthesis in the liver pathway, caused by decreased levels of

Correspondence to: Ana Paula Silva Azevedo dos Santos E-mail: apsazevedo@yahoo.com.br the enzyme porphobilinogen deaminase (PBGD), with subsequent accumulation of precursors deltaaminolevulinic acid (ALA) and porphobilinogen (PBG) (Anderson et al. 2001). AIP predominates in females and usually manifests itself after puberty, probably because of steroid hormones that are among the most important precipitating factors in the crisis (Andresson et al. 2003).

The main symptoms of AIP are related to overproduction of porphyrins and increased activity of the enzyme ALA synthase (ALAS) in the liver by 
action of some precipitating factors such as steroid hormones and porphyrinogenic drugs (Murray et al. 2007). Sassa (1996) states that abdominal pain is the most common symptom and it is often the first sign of an acute porphyria attack.

Clinical conditions involve autonomic neuropathy, peripheral neuropathy and brain dysfunction, progressing generally in the following order: first, severe abdominal pain; second, psychiatric manifestations and finally neurological disorders (Blom 1996). Nonspecific symptoms make the diagnosis difficult and peripheral neuropathy in AIP is usually locomotory and may take similar characteristics to those observed in Guillian-Barré Syndrome (Sisteré 2010). The laboratory data about the AIP has been described in other studies, however, case reports are few in Brazil and especially in Maranhão.

Considering AIP as a rare disease with nonspecific signs and symptoms that provides little information on its incidence in Brazil, in addition to the high cost of treatment and specific laboratory tests, this paper presents a case study of an AIP carrier in São Luis, state of Maranhão. The study analyzes the relationship of hematological and biochemical parameters that may help diagnose the disease, showing that it is possible to improve the clinical and biochemical picture with the use of oral contraceptives.

\section{MATERIALS AND METHODS}

\section{CASE Study}

This work dealt with a case study of an AIP carrier. The study was approved by the Research Ethics Committee of the Universidade Federal do Maranhão, protocol \# 23115-000413/2010-77. The method used was a not recorded interview, looking for information about symptoms from the early days of the crisis until the recovery stage. We have conducted a survey of medical information during the period of hospitalization and home care through hospital records, reports and examinations of the patient's own possession. From these data, we listed information on the hematological and biochemical tests performed and the patient's clinical evolution.

CASES

The patient was female, Caucasian, 28 years old, $1.68 \mathrm{~m}$ tall, weighed $62 \mathrm{~kg}$, had menarche at the age of 13 years with regular cycles and normal flow. She did not report any disease of great significance previous to porphyria attacks. The first attack of porphyria occurred at the age of 24 years and the second at the age of 28 years. Apparently, it was the first case in the family, with no other confirmed case of AIP.

Data analyzed in this work are related to the patient's second crisis, which occurred in January 2008 and corresponded to 115 days of hospital stay (intensive care unit, semi-intensive care unit and hospital room), plus the data for the last 2 years and 6 months of recovery at home.

\section{DATA TABULATION}

Clinical and laboratory data were distributed on a table regarding the time of clinical evolution. Thus, the period from the beginning of the AIP crisis until the date of diagnosis was defined as phase I, lasting 36 days; the period in which treatment of porphyria initiated until discharge from the hospital correspond to phase II, lasting 79 days; and the recovery period at home was defined as phase III, lasting 2 years and 6 months.

The clinical, biochemical and hematological parameters were organized in tables using Excel program (Microsoft). The daily values of each parameter were analyzed by comparing them with the respective reference values based on the methods of analysis.

STATISTICAL ANALYSIS

Statistical analysis was performed using GraphPad Prism for Windows (GraphPad Software, San Diego, 
California, USA). The samples showed a normal distribution (Gaussian), thus the biochemical and hematological data were expressed as line graphs and frequency analysis of values was performed in each evolutionary phase.

\section{RESULTS}

\section{Clinical MANifESTATIONS AND CASE REPORT}

\section{Phase I}

The patient reported that she was at the end of the menstrual cycle, with sore throat, abdominal pain and distension, constipation, nausea, vomiting, insomnia, progressing to fatigue in the legs, hip and scalp numbness, muscle weakness and knees instability.

Then, the abdominal pain became more intense with increased generalized muscle weakness, intense heat, agitation, and difficulty with swallowing, speaking and daily activities. The clinical picture over a week progressed to hallucinations, quadriplegia and respiratory arrest. The patient had to be intubated and stay on mechanical ventilation. During this phase, the patient had several diagnostic hypotheses such as intestinal blockage, gastritis, hepatitis, ulcer, appendicitis, infantile abdomen, depression, and Guillain-Barré syndrome, for which seven sessions of plasmapheresis were performed with no clinical improvement. Then, a qualitative analysis of porphobilinogen was performed on 24-hour urine, which showed to be positive, confirming the diagnosis of acute porphyria.

\section{Phase II}

The process of mechanical ventilation withdrawal was gradual. The initial treatment consisted of daily intravenous glucose, diet rich in carbohydrates, prescription of non porphyrinogenic drugs only, electrolyte replacement, physical therapy and speech-language pathology. At the end of this phase, the patient already showed improved locomotor control with a partial control of the trunk and improvement in facial movements, swallowing and speech.

\section{Phase III}

The patient began home physiotherapy and medical care and speech-language pathology, occupational therapy, physical therapy and hydrotherapy in the clinic Escola Santa Edwiges-São Luís, Brazil. Drug therapy was initiated with continuous use of oral contraceptive desogestrel $75 \mathrm{mcg}$, replacing the treatment that had been carried out for 6 six months with goserelin acetate $3.6 \mathrm{mg}$. The patient remained stable.

\section{HEMATOLOGY LABORATORY MANIFESTATIONS}

\section{Phase I}

Based on hematology laboratory data, at this phase the patient had a reduction in erythrocytes count, hemoglobin concentration and hematocrits at a frequency around $83 \%$ of the tests performed when compared with reference values. However, hematimetric indices as mean corpuscular volume (MCV), mean corpuscular hemoglobin ( $\mathrm{MCH})$ and mean corpuscular hemoglobin concentration (MCHC) were within the respective reference values, indicating a type of normocytic normochromic anemia. It was observed that the total leukocyte count was elevated in approximately $61 \%$ of the exams performed due to neutrophilia (Figure 1).

\section{Phase II}

Based on hematology laboratory data, the patient continued to show a reduction in total erythrocyte count, hemoglobin concentration and hematocrits at a frequency around $92 \%$ of the tests performed when compared with reference values. The values of hematimetric indices were normal. The total leukocyte count was elevated by approximately $23 \%$ of the 13 tests carried out due to neutrophilia (Figure 1). 

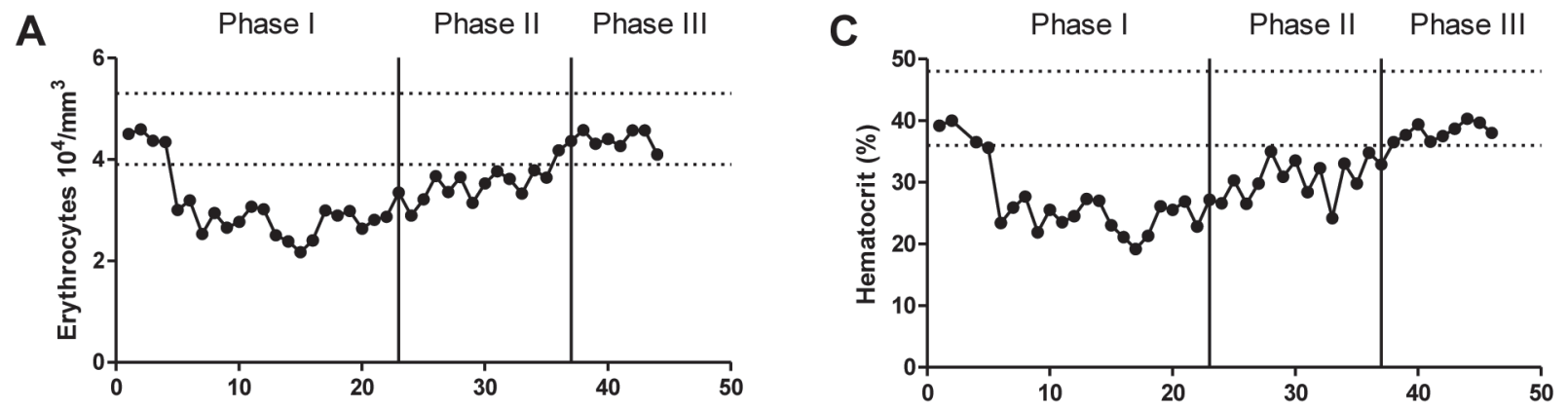

B
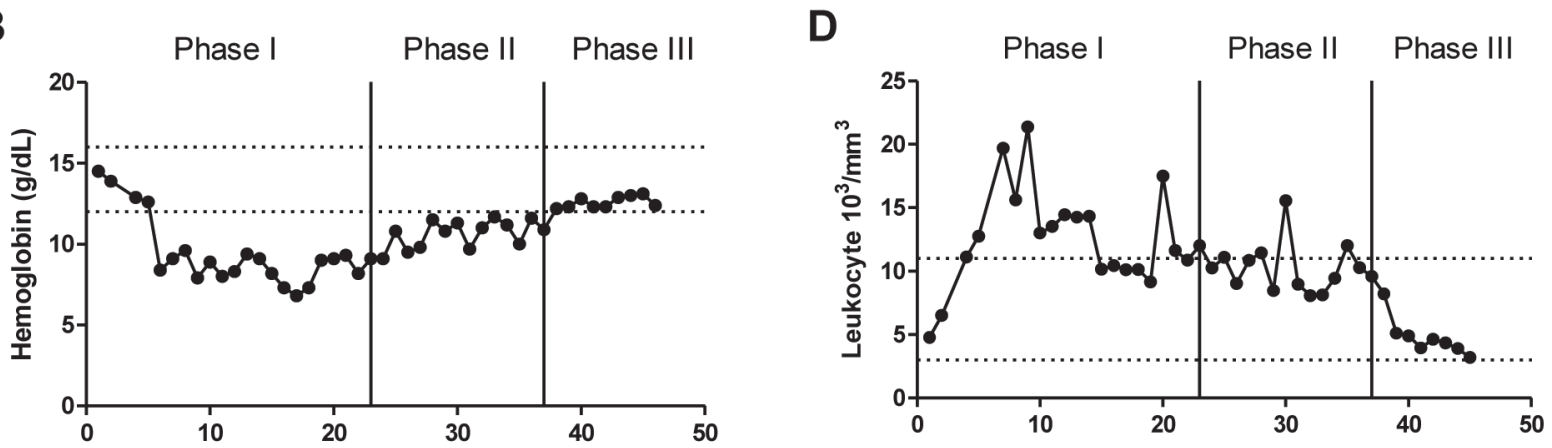

Figure 1 - Hematological parameters analyzed during phases I, II and III. Erythrocytes count (A), hemoglobin level (B), hematocrits (C) and leukocytes count (D). The upper and lower dotted lines represent the minimum and maximum reference values of each parameter respectively. Erythrocytes: 3.90-5.30 (millions $/ \mathrm{mm}^{3}$ ) hematocrits: 36.0-48.0 (\%), hemoglobin: 12.0-16.0 (g/dL), leukocytes: 3,600-11,000 ( $\left.\mathrm{mm}^{3}\right)$. Method of analysis: ADVIA 120 Automated Hematology Analyzer.

\section{Phase III}

Based on hematology laboratory data, the total count of erythrocytes, hemoglobin concentration and hematocrits showed values within the normal range. The values of hematimetric indices were normal. The total leukocyte count showed $85.5 \%$ frequency within normal limits in eight tests performed (Figure 1).

BIOCHEMICAL LABORATORY MANIFESTATIONS

\section{Phase I}

In biochemical parameters, sodium showed $21 \%$ of values below the minimum reference in 19 tests. Potassium levels were approximately $18 \%$ below the minimum reference in 22 tests. Regarding urea levels, values were within the normal range in approximately $70 \%$ of 16 tests, while values of C-reactive protein (CRP) were elevated in approximately $85 \%$ of 13 tests (Figure 2).

\section{Phase II}

In biochemical parameters, sodium showed 23\% of values lower the minimum reference in 13 tests and potassium levels were normal throughout the phase. Values of serum sodium concentrations were normalizing, especially at the end of the phase. Regarding urea levels, values were around $91 \%$ above the normal range in 16 tests performed, as well as CRP values, which were high throughout the phase. At this time, no qualitative and quantitative analysis of ALA and PBG were performed on the urine of the patient.

Phase III

In biochemical parameters, at this stage, sodium was normal in all 7 tests performed, as well as potassium. Regarding urea levels, all values were above the normal range in 6 tests. On the other hand, CRP values were normal, with a frequency of $75 \%$ in 4 tests performed (Figure 2). 

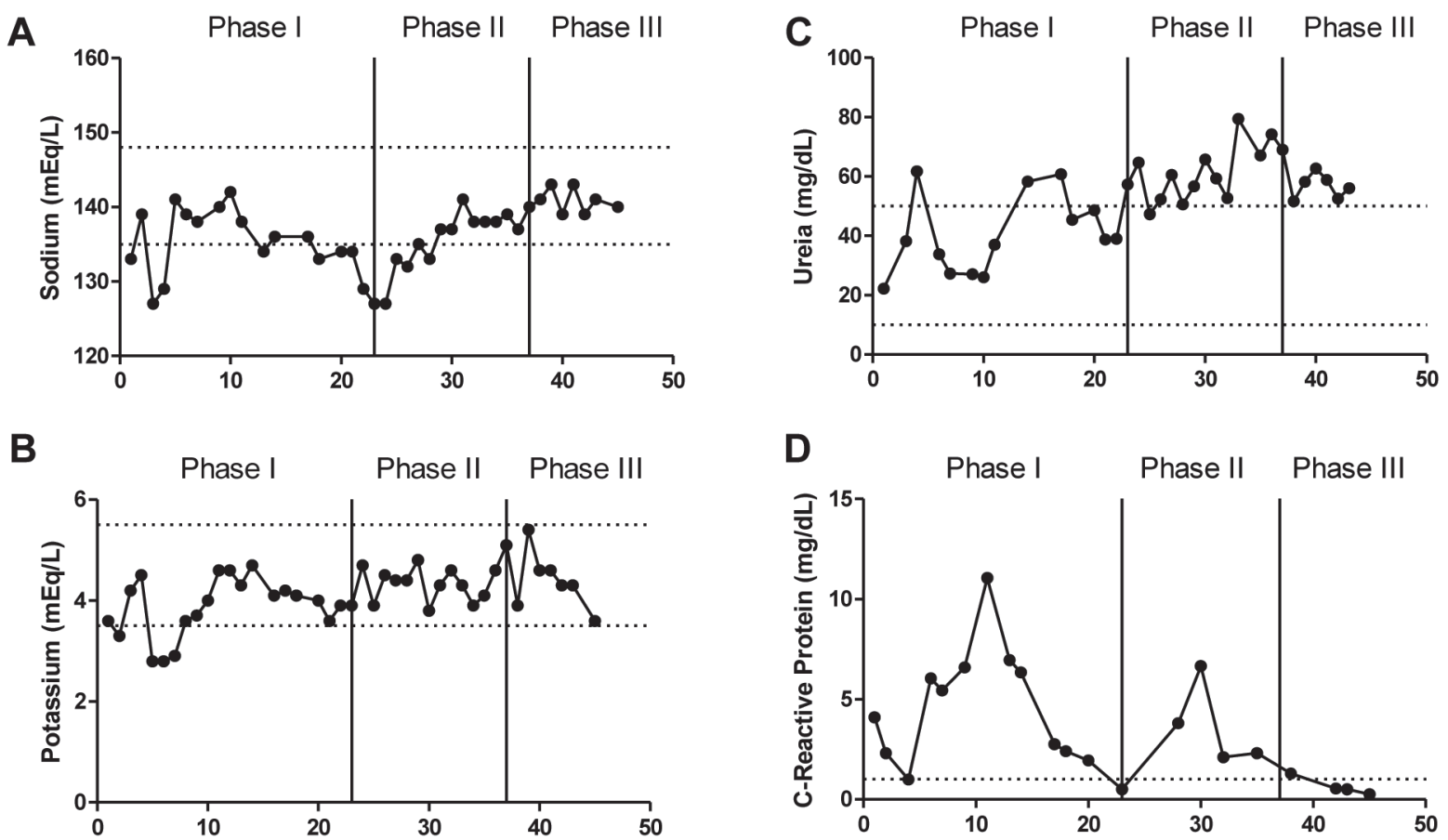

Figure 2 - Biochemical parameters analyzed during phase I, II and III. Sodium concentration (A), serum potassium concentration (B), serum urea concentration (C) and serum C-reactive protein concentration (D). The upper and lower dotted lines represent the minimum and maximum reference values of each parameter respectively. Sodium: 135.0-148.0 mEq/L, urea: $10-50 \mathrm{mg} /$ $\mathrm{dL}$, potassium: 3.50-5.50 mEq/L, C-reactive protein: Up to $1 \mathrm{mg} / \mathrm{dL}$. Method of analysis: selective electrode for sodium and potassium, colorimetry for urea and turbidimetry for C-Reactive Protein.

During this phase, 5 quantitative tests of $\mathrm{PBG}$ and ALA were performed on the 24-hour urine. PBG levels were normal in all tests, while ALA values were above normal in the first test (Table I).

Endogenous sex hormones levels, such as estradiol, progesterone, follicle stimulating hormone (FSH) and luteinizing hormone (LH) were obtained. The first test was performed when the patient was in the luteal phase of the menstrual cycle; estradiol was above normal and the rest was normal (Table II). In a second hormone test, the patient was in menopause induced by goserelin acetate $3.6 \mathrm{mg}$ and the levels of estradiol, progesterone and SHBG were normal, whereas FSH and LH levels were below normal (Table III).

\section{DISCUSSION}

In the case studied, the sex of the patient and the age at which the crisis occurred correlate with the
TABLE I

Values of ALA and PBG metabolites levels on 24-hour urine of nine analyzes performed.

\begin{tabular}{ccc}
\hline \multirow{2}{*}{ Analyses } & $\begin{array}{c}\text { ALA (mg/g of } \\
\text { creatinine) }\end{array}$ & PBG (mg/24 hours) \\
\cline { 2 - 3 } & $\begin{array}{c}\text { Reference: up to 4,5 } \\
\text { mg/g of creatinine }\end{array}$ & $\begin{array}{c}\text { Reference: Inferior a } \\
2 \mathrm{mg} / 24 \text { hours }\end{array}$ \\
\hline $1^{\circ}$ & - & 1.22 \\
\hline $2^{\circ}$ & 5.10 & - \\
\hline $3^{\circ}$ & - & 1.04 \\
\hline $4^{\circ}$ & 4.80 & - \\
\hline $5^{\circ}$ & - & 1.13 \\
\hline $6^{\circ}$ & 7.46 & - \\
\hline $7^{\circ}$ & - & 1.10 \\
\hline $8^{\circ}$ & 8.45 & - \\
\hline $9^{\circ}$ & 4.47 & 0.60 \\
\hline
\end{tabular}

literature that describes prevalence of AIP cases in females. Usually the first symptoms manifest after puberty (Gross et al. 1995). As shown in a study 
carried out in northern Sweden, among the cases of AIP carriers analyzed, there was $63.7 \%$ predominance of females in the manifest group, as opposed to the latent group in which women had only $37.6 \%$ of cases identified (Andresson et al. 2003).

TABLE II

Values of estradiol, progesterone, FSH, LH and SHBG levels during the luteal phase.

\begin{tabular}{ccc}
\hline Hormone & Values & Reference \\
\hline Estradiol $(\mathrm{pg} / \mathrm{ml})$ & 363.2 & $43.8-211$ \\
\hline Progesterone $(\mathrm{ng} / \mathrm{ml})$ & 14.52 & $1.70-27$ \\
\hline FSH $(\mathrm{mUI} / \mathrm{ml})$ & 2.00 & $1.7-7.7$ \\
\hline LH $(\mathrm{mUI} / \mathrm{ml})$ & 3.5 & $1-11.4$ \\
\hline
\end{tabular}

TABLE III

Values of estradiol, progesterone, FSH, LH and SHBG levels during the induced menopause.

\begin{tabular}{ccc}
\hline Hormone & Values & Reference \\
\hline Estradiol $(\mathrm{pg} / \mathrm{ml})$ & 27.2 & $10-50$ \\
\hline Progesterone $(\mathrm{ng} / \mathrm{ml})$ & 0.43 & $0.1-1$ \\
\hline FSH $(\mathrm{mUI} / \mathrm{ml})$ & 4.23 & $16.6-165$ \\
\hline LH $(\mathrm{mUI} / \mathrm{ml})$ & 0.49 & $15.9-54$ \\
\hline
\end{tabular}

Endogenous female hormones play animportant role in triggering a crisis of AIP (Andresson et al. 2003). The reduction of steroid hormones in the liver is catalyzed by two classes of enzymes: $\Delta^{4}$ $5 \alpha$-reductase and $\Delta^{4}-5 \beta$-reductase. Patients with porphyria have a deficiency in the activity of $\Delta^{4}$ $5 \alpha$-reductase, leading to disproportional generation of $5 \beta$-steroid metabolites, thus inducing porphyria (Bradlow et al. 1973).

Clinical symptoms of AIP are related to excess production of porphyrin precursors and increased activity of the enzyme ALA synthase (ALAS) in the liver by action of some precipitating factors such as steroid hormones and porphyrinogenic drugs (Murray et al. 2007).

In laboratory manifestations, anemia caused by a decrease in the biosynthesis of heme in erythroid precursor cells from bone marrow leads to a generation of microcytic and hypochromic type of anemia (Oliveira and Poly 2004). However, in this study, the patient had normocytic and normochromic type of anemia. Thus, our observations suggest that there is a reduction in the number of erythrocytes generated in bone marrow and this assumption agrees with the findings of Winkler et al. (2003) who reported that patients with porphyria and showing neuropsychiatric symptoms have low levels of erythropoietin and its use for treatment can reduce attacks.

The patient had leukocytosis due to neutrophilia in the first two phases of the AIP crisis. Plugia (2001) points out that in $10 \%$ to $40 \%$ of cases, leukocytosis and fever are followed by abdominal pain, mimicking abdominal inflammatory processes. Among laboratory abnormalities, leukocytosis is the second most frequent. Another factor that may have contributed to neutrophilia was that the patient had bacterial pneumonia signs during the crisis.

In the analysis of biochemical parameters, the patient had hyponatremia along with mild hypokalemia. Electrolytic disorders are the most frequent biochemical signals, and hyponatremia the most common (Lopes et al. 2008). In many cases due to loss of gastro-intestinal sodium or, although not yet confirmed, by kidney damage, fluid overload and reduced secretion of antidiuretic hormone (Rios et al. 2008). However, in this case study, changes in serum sodium followed by a mild hypokalemia were observed. Thereby, data observed in this study are in accordance with the hypothesis proposed by Anderson et al. (2001) who suggest that the cause of hyponatremia is excessive sodium loss via gastrointestinal tract and low sodium diet.

Analyzing the levels of urea in the three phases, it is worth noting that the patient underwent seven sessions of plasmapheresis during phase I, which may have contributed to normalize the levels of urea. Because plasma levels of urea were higher in the subsequent phases and creatinine levels (not informed) were normal, it is believed that the patient did not have kidney injury. As urea is synthesized in the liver 
by using ammonia derived from the catabolism of exogenous and endogenous proteins (Murray et al. 2007) - a hypothesis for the cause of uremia - this catabolism of proteins would have normal synthesis as opposed to decreased production of heme.

Another biochemical parameter analyzed was the C-reactive protein (CRP), which is a plasma protein of acute phase produced in the liver and used as a marker of tissue injury, infection and inflammation (Murray 2007). Goldberg (1959) demonstrated that porphobilinogen is synthesized in the liver, thus AIP is a hepatic metabolic disorder. Thereby, this metabolic disorder would be a possible cause of elevated CRP values. This has proved to be an important biochemical marker that could contribute to the diagnosis.

Quantitative analysis of heme metabolites were only carried out in phase III, in which PBG values were normal, while ALA was high. The elevation of ALA with normal PBG values can be caused by ALAS hepatic induction due to the action of steroid hormones metabolites (Kappas et al. 1972).

The treatment of AIP is based on specific therapies to reduce the levels of heme precursors and treatment of the disease symptoms. In the attacks of porphyria, treatment with hematin is important because it would be a biochemical blocker of the metabolic pathway of heme (Pierach et al. 1980). Glucose and other carbohydrates are also effective for treatment, because they reduce the synthesis of porphyrins (Plugia 2001). The study highlights that the use of oral contraceptives stabilizes the latent phase of the disease, preventing premenstrual acute attacks of AIP. Studies have been discussing the benefits and risks of using luteinizing hormonereleasing hormone (LHRH) agonists, which has shown promising results. LHRH agonists suppress the endogenous production of hormones, thus preventing premenstrual attacks (Lacy et al. 2006).

In the analyses of serum levels of sex hormones, the patient had elevated estradiol levels, which is a precipitating factor for porphyria crisis. However, treatment of the patient with $3.6 \mathrm{mg}$ goserelin acetate - an LHRH - led to a drop in levels of estradiol and was subsequently replaced by the use of $75 \mathrm{mcg}$ desogestrel. It provided a clinically stable condition and normalized the levels of PBG and ALA, thus avoiding possible premenstrual attacks. In the second hormonal analysis, which refers to the phase of induced menopause, levels of FSH and LH were below the reference, disagreeing with levels often observed in women during menopause.

The diagnosis of acute porphyria is possible during the existence of clinically relevant features of this disease, but in most cases, the signs and symptoms are highly nonspecific, being necessary to obtain the levels of ALA and PBG on urine in order to confirm the disease (Prauchner and Emanuelli 2002). Although the data did not show novelty in laboratory aspects, they demonstrated how routine tests may help in early diagnosis of AIP. Thus, this work found thatthe presence of gastrointestinal and neuropsychiatric signs and symptoms, associated with the laboratory results presented in this study - when other tests show to be normal - can be a strong predictor of acute intermittent porphyria.

\section{ACKNOWLEDGMENTS}

We thank to UDI Hospital in the city of São Luis, Maranhão, for supplying the patient's medical records. This work was supported by Fundação de Amparo à Pesquisa e Desenvolvimento Científico do Maranhão (FAPEMA).

\section{RESUMO}

A Porfiria Aguda Intermitente é a mais comum das porfirias agudas, é causada por uma diminuição hepática da atividade do porfobilinogênio deaminase, ocasionando um acúmulo do ácido delta-aminolevulínico e porfobilinogênio. Esta doença apresenta sinais e sintomas inespecíficos que podem ser confundidos com outras patologias, dificultando assim o diagnóstico. Relatamos um caso de porfiria aguda intermitente, revisando aspectos clínicos e laboratoriais, destacando os parâmetros 
hematológicos e bioquímicos durante e após a crise. Paciente do sexo feminino, 28 anos, sofreu duas crises, apresentando ambas distúrbios gastrointestinais, sendo que a segunda apresentou sintomas neuropsiquiátricos. $\mathrm{Na}$ análise dos parâmetros hematológicos e bioquímicos, durante a segunda crise, A mesma apresentou anemia, leucocitose, hiponatremia, hipocalemia leve, uremia e proteína $\mathrm{C}$ reativa elevada. $\mathrm{O}$ tratamento inicial foi com infusão de glicose, alimentação rica em carboidratos e suspensão dos medicamentos porfirinogênicos, sendo posteriormente mantido com uso de contraceptivo oral. De acordo com os dados observados, sinais e sintomas gastrointestinais, neurológicos e psiquiátricos, associados aos resultados laboratoriais apresentados neste trabalho, estes podem ser aplicados para a triagem de profiria aguda, contribuindo para o diagnostico precoce.

Palavras-chave: porfiria aguda intermitente, anemia, proteína c reativa, hiponatremia.

\section{REFERENCES}

Anderson KE, SASSA S, BISHOP DF AND DESNICK RJ. 2001. Disorders of heme biosynthesis: X- linked sideroblastic anemia and the porphyrias, In : SCRIVER CR, BEAUDIT AL, SLY WS, VALLE D, CHILDS B, KENZLER KW AND VOGELSTEIN B (Eds), The online metabolic and molecular bases of inherited disease, $8^{\text {th }}$ ed., New York: McGraw-Hill, Cap. 124, p. 36-61.

ANDRESSON NC, INNALA E AND BACKSTROM T. 2003. Acute intermittent porphyria in women: clinical expression, use and experience of exogenous sex hormones. A population-based study in northern Sweden. J Intern Med 254: 176-183.

Blom H, Andersson C, OlofsSom BO, BJerle P, WiKLund U AND LITHNER F. 1996. Assessment of autonomic nerve function in acute intermittent porphyria: a study based on spectral analysis of hear rate variability. J Intern Med 240: 73-79.

BRADLOW HL, GILlETte PN, Gallagher TF AND KaPPAS A 1973. Studies in porphyria. II Evidence for a deficiency of steroid $\Delta^{4}-5 \alpha$-redutase activity in acute intermittent porphyria. J Exp Med 138: 754-763.

GOLDBERG A. 1959. Acute intermittent porphyria. A study of 50 cases. Quart J Med 110: 183-209.
Gross U, Honcamp M, Daume E, Frank M, Dusterberg B AND Doss MO. 1995. Hormonal oral contraceptives, urinary porphyrin excretion and porphyrias. Horm Metab Res 27(8): 379-383.

Kappas A, BRADLOW HL, GILlETte PN AND Gallagher TF. 1972. Studies in porphyria. I A defect in the reductive transformation of natural steroid hormones in the hereditary liver disease, acute intermittent porphyria. New York. J Exp Med 136: 1043-1053.

LaCy J, Kives S, IpP M, ORNestein M AND Allen L. 2006. Premenstrual attacks of acute intermittent porphyria in an adolescent female. Toronto. J Pediatr Adolesc Gynecol 19(5): 357-358.

Lopes DVA, Valle AM, TAGUti J, TAGUTI RCTC, Betônico GN AND MEdeIRos FC. 2008. Porfiria aguda intermitente: relato de caso e revisão da literatura. Presidente Prudente. Rev Bras Ter Intensiva 20(4): 429-434.

MurRay RK, GRANNER DK AND RODWELl VW. 2007. Harper: bioquímica ilustrada. $27^{\text {th }}$ ed., São Paulo. McGrawHill, p. 263-274.

Oliveira RAG AND Poli NA. 2004. Anemias e Leucemias: conceitos básicos e diagnóstico por técnicas laboratoriais. São Paulo. Roca, p. 35-48.

Pierach CA, Bossenmaier I, CARdinal R, Weimer M AND WATSON CJ. 1980. Hematin Therapy in Porphyric attacks. J Mol Med 58(16): 829-832.

Plugia PMK. 2001. Pofiria aguda intermitente: estudo de 37 casos. 222 f. Dissertação (Mestrado em Neurologia)Faculdade de Medicina da Universidade de São Paulo. Biblioteca digital-USP. (Unpublished).

Prauchner CA ANd Emanuelli T. 2002. Porfirias agudas: aspectos laboratoriais. Santa Maria. Rev Bras Cienc Farm 38(3): 249-257.

Ríos CCL, Duran FG, Moros ET, Martin JAC, Alcol BP PRUdENCIO SS, FANDO PVL, José FBS AND AGUlló JLR. 2008. Dolor abdominal y síndrome de secreción inadecuada de hormona antidiurética (SIADH) en un paciente diagnosticado de porfiria aguda intermitente. Madrid. Rev Esp Enferm Dig 100(4): 247-248.

SASSA S. 1996. Diagnosis and therapy of acute intermittent porphyria. Blood Rev 10(1): 53-58.

Sisteré IG, MaVILA KL, RiBElles JC, LÓPEZ CT. 2010. La porfiria aguda intermitente, un problema diagnóstico. Espanã. Gastroenterol Hepatol 33(6): 436-439.

Winkler AS, Peters TJ, Marsden JT, Deacon AC, CHANDLER G AND MACDOUgall LC. 2003. Erythropoietin treatment in the neuropsychiatric porphyrias. London. Clin Chim Acta 338(1): 61-66. 